\title{
Ko-infeksi Human Immunodeficiency Virus (HIV) dengan Mycobacterium leprae
}

\author{
Yuni Eka Anggraini*
}

\begin{abstract}
Human immunodefficiency virus (HIV) epidemic covers several countries with endemic leprosy without any significant increase in the number of patients co-infected with HIV and leprosy, so it can be concluded that HIV-positive does not increase the risk of developing leprosy. Clinicopathological spectrum of leprosy patients who are co-infected with $\mathrm{HIV}$ is not changed. Leprosy may be attributed to the presence of immune recovery syndrome after the administration of highly active antiretroviral therapy (HAART). Long-term incubation period and the low incidence of leprosy in patients with HIV make prospective cohort or case-control studies on the prevalence of leprosy among a group of HIV positive and HIV negative hardly possible to be performed. The benefit of this circumstance is the HIV pandemic does not become a nuisance of the effort to control leprosy. Further studies on the molecular pathogenesis of $M$. leprae and other mycobacterial can provide an understanding of the differences of the pathogenesis in patients with HIV infection.
\end{abstract}

Keywords : co-infected, HIV, M.Leprae

Lepra merupakan penyakit infeksi kronis melibatkan kulit dan saraf tepi yang disebabkan oleh bakteri intraselular M. leprae. Insidensi kasus baru lepra menetap pada 286.000 kasus per tahun. ${ }^{1}$ Saat ini di beberapa negara dengan endemi lepra seperti India, Brazil, Congo, Nepal, dan Mozambiq yang mempunyai angka tertinggi untuk kasus baru lepra didaptkan peningkatan prevalensi infeksi HIV. ${ }^{2}$ Meskipun jumlah pasien yang mengalami koinfeksi belum dapat ditentukan, peningkatan secara geografis daerah dengan kedua jenis penyakit ini sangat memungkinkan seorang individu dapat terinfeksi keduanya secara bersamaan. ${ }^{3}$

Sejak ditemukannya efek infeksi HIV pada insidensi dan gambaran klinikopatologi tuberkulosis, perhatian mulai ditujukan pada epidemi HIV dan lepra yang mungkin mempunyai interaksi yang sama. ${ }^{4}$ Infeksi HIV mempunyai efek pada insiden dan gambaran klinikopatologi penyakit mikobakteria yang lain seperti tuberkulosis, sehingga diduga hal ini juga ditemukan pada interaksi HIV dengan lepra. Pada koinfeksi HIV dengan $M$. tuberculosis, interaksi keduanya ditandai dengan supresi imun yang terjadi setelah

\footnotetext{
* Penulis untuk korespondensi : Bagian Ilmu Kulit dan Kelamin Fakultas Kedokteran Universitas Riau,

Alamat : Jl. Diponegoro No. 1 Telp. 0761-839264, ext 209
}

infeksi HIV yang mempercepat progresivitas tuberkulosis, dan sebaliknya aktivasi imun selular pada tuberkulosis berhubungan dengan progresivitas infeksi HIV yang lebih cepat., ${ }^{1,3}$

Pada awal epidemi HIV, para ahli memperkirakan bahwa infeksi HIV akan memperburuk penyakit lepra dengan banyaknya pasien yang berkembang menjadi tipe lepromatosa karena infeksi HIV menyebabkan hilangnya imunitas seluler sehingga infeksi oportunistik terjadi lebih cepat, akan tetapi terbatasnya data terkait epidemiologi dan aspek klinik lepra mengindikasikan perjalanan penyakit lepra tidak secara signifikan terpengaruh oleh infeksi HIV. Pada koinfeksi HIV dengan M. leprae, defisiensi imun karena infeksi HIV diduga akan mengubah spektrum lepra menjadi kutub lepromatosa (Th2), meskipun data epidemiologis jarang dan berlawanan. ${ }^{1}$ Tinjauan pustaka ini lebih jauh akan melihat hubungan antara ko-infeksi HIV dan lepra berdasarkan publikasi yang ada.

\section{PATOGENITAS MYCOBACTERIUM LEPRAE}

Mycobacterium leprae merupakan bakteri tahan asam dan gram positif intraseluler obligat yang mempunyai tropisme terhadap sel sistem 
retikuloendotelial dan sistem syaraf tepi ( sel Schwann). Replikasi M. leprae melalui pembelahan yang lambat dalam 12 hingga 13 hari. Masa inkubasi lepra bervariasi tergantung tipe lepra, yaitu tipe tuberkuloid 2-5 tahun dan tipe lepromatosa 5 - 15 tahun. Predisposisi tempat infeksi adalah pada area dingin seperti kulit, mukosa hidung, dan syaraf tepi terutama bagian superfisial. M. leprae tumbuh paling baik pada suhu antara $27^{\circ} \mathrm{C}$ dan $30^{\circ} \mathrm{C} .^{5}$

Patogenitas M. leprae ditentukan berdasarkan elemen struktural yang dimiliki oleh bakteri tersebut yaitu kapsul dan dinding sel. Kapsul terdiri dari sejumlah besar lipid terutama phthiocerol dimycocerosate dan phenolic glucolipid-1 (PGL1) yang menjadi target respons imun humoral yang diperantarai IgM. Protein PGL-1 akan merusak komplek DRP2-dystroglycan pada sel Schwann, menyebabkan rusaknya mielinisasi. Sel Schwann yang bermielin memproduksi DRP2 yang penting untuk mielinisasi. Komponen penting yang lain dari dinding sel adalah lipoarabinomannan(LAM) yang menjadi antigen bagi makrofag. Secara biologis fungsi LAM antara lain menghentikan aktivasi sel T, inhibisi berbagai fungsi yang diinduksi IFN-ã termasuk aktivitas tumorisidal dan mikrobisidal makrofag, inhibisi aktivitas protein kinase C, dan membangkitkan sebagian besar sitokin yang berhubungan dengan makrofag seperti TNF-á, granulocytemacrophage-CSF, IL-1a, IL-1b, IL-6, dan IL-10. ${ }^{6}$

Perkembangan penyakit dengan berbagai manifestasi klinis tergantung pada status imun pasien dan genetik. Banyak komponen sistem imun yang berhubungan dengan fenotip klinis dan perjalanan penyakit. Respons seluler yang spesifik dan terorganisir dapat dilihat pada kasus di kutub tuberkuloid, sedangkan hilangnya respons imun spesifik terlihat pada kutub lepromatosa. Pada kutub Th1 atau tuberkuloid (pausibasiler), lepra ditandai dengan adanya level imunitas yang tinggi diperantarai sel yang secara efektif membatasi replikasi bakteri dan berhubungan dengan pembatasan penyakit, meskipun dapat sering dengan terjadi kerusakan pada syaraf. ${ }^{1}$ Bentuk tuberkuloid mempengaruhi kulit dan syaraf tepi menyebabkan plak infiltratif yang berbatas tegas, berbentuk anular atau ovoid. Lesi kulit biasanya anestesi. Biopsi kulit dan daerah sekitar syaraf tepi memperlihatkan bakteri tahan asam yang jarang atau sedikit, granuloma dengan histiosit epiteloid yang banyak, multinucleated giant cells, dan sel T CD4+ yang mensekresikan interferon-ã. Pada kutubTh2/ tipe lepromatosa, atau multibasiler, lepra ditandai dengan tidak ditemukannya respons imun spesifik/ selektif antigen $M$. leprae terhadap aktifitas menyebaran di kulit dan multiplikasi organisme yang tidak terkontrol di kulit. Basil lepra mengalami prolifersi pada jaringan dan makrofag yang berbuih dengan jumlah CD4+ sel T dan CD8+ sel T sedikit, dan granuloma biasanya tidak terbentuk. Penemuan imunohistokima pada kulit biopsi pada umumnya adalah interleukins (IL) 4 dan 10. IL-4 akan memicu limfosit T CD4+ (Th-2) yang berhubungan dengan imunitas humoral. ${ }^{7}$

Peran genetik pada infeksi lepra antara lain terkait lokus yang suseptibel ditemukan pada 10p13 di dekat gen mannose receptor. Reseptor mannose terdapat pada permukaan makrofag yang penting pada proses fagositosis. Komplek gen class II HLA/ MHC pada kromosom 6 memberikan implikasi pada tipe lepra yang akan berkembang pada pasien. Gen HLA-DR2 dan HLA-DR3 berhubungan dengan lepra tuberkuloid sedangkan HLA-DQ1 paliang banyak ditemukan pada pasien dengan bentuk lepromatosa. Mutasi pada gen PARK2 dan PACRG pada individu akan meningkatkan suseptibilitas terhadap lepra. Fungsi protein NRAMP1 yang normal akan membuat individu kurang suseptibel terhadap infeksi $M$. leprae karena bakteri tersebut akan cepat terdeteksi dalam tubuh. ${ }^{5}$

\section{PATOGENITAS HUMAN IMMUNODE FICIENCY VIRUS (HIV)}

Virus HIV masuk dalam keluarga (family) retroviridae, yaitu virus RNA yang harus berubah menjadi DNA sebelum replikasi. ${ }^{8,9}$ Virus HIV berbentuk sferis mempunyai diameter sekitar 100 $180 \mathrm{~nm}$ dan menghasilkan 15 jenis protein yang terkombinasi untuk membuat virion menjadi infeksius (Gambar 3). ${ }^{10}$ Semua bagian virion dibuat oleh virus itu sendiri kecuali lipid bilayer (lipid lapis ganda) yang berasal dari sel yang terinfeksi melalui proses budding. Lipid membran yang berasal dari sel inang dan berisi glikoprotein virus gp120 dan gp41 yang berasal dari gp160. ${ }^{11} \mathrm{Gp} 120$ mempunyai domain protein variabel yang multipe dan salah satunya disebut V3 loop yang dapat membangkitkan 
respons imun yang kuat. Sejumlah antibodi penetral menjadikan daerah ini sebagai target, sehingga terjadi seleksi mutasi yang kuat pada bagian ini. ${ }^{10} \mathrm{Pada}$ saat invasi sel, HIV mengambil alih fungsi sel TCD4+ menjadi sel yang digunakan HIV untuk reproduksi. CD4 merupakan determinan mayor dari tropisme virus yang diekspresikan sebagian besar pada permukaan sel $\mathrm{T}$ dan sel lain seperti makrofag, monosit, dan sel dendritik. ${ }^{10}$

Virus HIV secara selektif menginfeksi dan berkembang biak dalam sel T CD4+ sehingga efek sitopatik tersebut merusak sel. Hampir semua sel terinfeksi akan mati dalam 12 hari setelah infeksi. Sel CD4+ yang terinfeksi HIV akan menularkan pada sel sehat yang lain. Sel limfosit T CD4+ berkurang juga disebabkan karena adanya apoptosis yang berlebihan dan sitolisis oleh sel CD8+. Karena sel CD4+ merupakan sel yang penting untuk melaksanakan kooperasi dalam respon imun, pengurangan jumlah dan gangguan fungsi sel CD4+ mengakibatkan supresi respons imun. Supresi ini tampak dalam penurunan kadar IL-2, IFN-ã, dan TNF-á. Hal ini menyebabkan penderita dengan infeksi HIV mengalami infeksi oportunistik oleh mikroorganisme intraselular seperti $M$. tuberculsosis, P. carinii, dan sitomegalovirus. ${ }^{12}$

Infeksi M. leprae berbeda dalam beberapa hal dengan $M$. tuberculosis sehingga tidak dimasukkan ke dalam infeksi oportunistik pada HIV. Perbedaan tersebut antara lain adalah $M$. leprae mempunyai properti bakterial spesifik seperti dijelaskan di atas, adanya evolusi gradual penyakit, spektrum klasik dari manifestasi klinis terkait dengan respons terhadap Th1dan Th2 inang, serta banyaknya beban antigen yang lambat hilang yang menyebabkan perubahan spontan repson imun inang sehingga terjadi reaksi lepra. Perbedaan ini dihubungkan dengan interaksi M.leprae dan infeksi HIV sehingga belum dapat dijelaskan dengan pasti apakah infeksi M.leprae juga mempunyai efek yang sama dengan infeksi M.tuberculosis pada pasien HIV. ${ }^{1}$

Peranan respons imun diperantarai sel yang spesifik untuk virus, khususnya aktivitas $C D 8+T$ cell toxicity memegang peranan penting pada kontrol awal infeksi HIV sebelum muncul pengikatan antiHIV atau menetralkan antibodi. ${ }^{11}$ Antibodi yang spesifik terikat pada antigen HIV akan mencegah infeksi sel (netralisasi),atau membantu eliminasi sel yang terinfeksi melalui mekanisme yang dikenal sebagai Antibody-Dependant Cellular Cytotoxicity (ADCC) yang diperantarai oleh limfosit $\mathrm{T}$ dan natural killer cells (sel NK). Walaupun respon imun untuk eliminasi virus terus berjalan, imunitas antiviral tersebut tidak dapat menghilangkan infeksi, hal ini disebabkan karena adanya persistensi virus yang terintegrasi pada kompartemen limfoid (reservoir) dengan ekspresi antigen virus yang rendah serta frekuensi mutasi genom virus yang tinggi merupakan cara virus untuk melarikan diri dari sistem imun, sehingga replikasi virus terus terjadi pada kompartemen limfoid. ${ }^{13}$

\section{KO-INFEKSI HIV DAN M. Leprae}

Infeksi HIV dan risiko terkena lepra diungkapkan pada beberapa penelitian kecil yang dipublikasi tahun 90-an memperlihatkan insidensi HIV tidak meningkat diantara pasien lepra bila dibandingkan dengan pasien tanpa lepra. ${ }^{2}$ Infeksi HIV dan bentuk klinis penyakit lepra pada awalnya diperkirakan akan menyebabkan pasien lepra berkembang ke arah tipe lepromatosa. Tipe lepra yang dilaporkan pada pasien ko-infeksi dengan HIV pada 2 studi dari Afrika Barat awal 90-an melaporkan peningkatan kasus $\mathrm{MB}^{3}$, sebaliknya sebuah studi di Brazil melaporkan kasus PB yang lebih dominan ${ }^{4,14}$, serupa dengan penelitian observasional besar yang dilaporkan dari Brazil oleh Sarno dkk, tentang ko-infeksi lepra dan HIV. Penelitian tersebut mengungkapkan pada pasien koinfeksi, lepra tuberkuloid adalah bentuk yang paling dominan dengan 78\% pasien HIV ko-infeksi dengan lepra tipe $\mathrm{PB}$ dibandingkan dengan distribusi yang lebih seimbang antara lepra bentuk PB (50,6\%) vs the MB (49,4\%) di antara pasien lepra dengan HIV negatif. Di antara semua pasien lepra bentuk MB, indeks bakterial (IB) pada grup dengan HIV positif lebih rendah dibanding grup dengan lepra saja. Pada umumnya pasien ko-infeksi terdiagnosis HIV sebelum lepra. Dari 33 pasien yang diukur viral load, diagnsosis lepra terjadi pada pasien yng mempunyai viral load rendah dan CD4 yang tinggi. ${ }^{15}$

Semua studi yang dipublikasi pada umumnya melihat seroprevalence HIV di antara studi kohort lepra sebelumnya atau pada seri pasien lepra yang baru terdiagnosis dibandingkan dengan kelompok kontrol. ${ }^{2}$ Kebanyakan studi menemukan tidak 
adanya perbedaan bermakna pada seroprevalence HIV antara kelompok kontrol dan kelompok kasus. Secara umum, studi-studi yang ada menunjukkan bahwa peningkatan pada prevalensi HIV diantara pasien lepra cenderung kecil dan lebih rendah dibanding pada pasien dengan tuberkulosis atau penyakit berhubungan dengan Mycobacterium avium ${ }^{3}$.

Studi di Ethiopia menjelaskan bahwa infeksi HIV bukan merupakan faktor risiko untuk berkembangnya reaksi reversal, meskipun pasien HIV cenderung lebih tinggi untuk kekambuhan reaksi reversal (reaksi tipe 1). Hal ini diduga karena fungsi fagositik makrofag dapat terganggu oleh infeksi HIV sehingga angka bersihan antigen $M$. leprae dari jaringan ikut terganggu akibatnya kecenderungan reaksi meningkat ${ }^{3}$, sementara itu data tentang reaksi tipe 2 (erythema nodosum leprosum/ENL) pada pasien ko-infeksi sangat sedikit. Studi AMFES (ALERT MDT Field Evaluation Study) melaporkan reaksi ENL lebih tinggi pada pasien ko-infeksi, tetapi hanya 3 pasien yang diobservasi. Berdasarkan penelitian yang dilakukan oleh Sarno dkk., reaksi lepra terutama reaksi tipe 1 banyak ditemui setelah pemberian HAART ${ }^{4,15}$ Gambaran ini memperlihatkan bahwa pasien ko-infeksi berisiko tinggi untuk berkembang menjadi reaksi, terutama saat mengkonsumsi ART. ${ }^{15}$

Pasien dengan HIV juga mempunyai risiko tinggi untuk berkembangnya kerusakan syaraf tepi termasuk neuropati perifer . Asumsi yang didapat adalah bahwa ko-infeksi HIV akan memperburuk kerusakan syaraf pada pasien lepra. Penelitian pada tahun 1990 menemukan bahwa kerusakan syaraf pada umumnya meningkat pada pasien ko-infeksi HIV dengan lepra. Penelitian prospektif dibutuhkan untuk melihat kemungkinan kerusakan syaraf pada lepra yang diperburuk oleh infeksi HIV. ${ }^{15}$

Studi histopatologi memperlihatkan infeksi HIV mempunyai pengaruh lebih sedikit pada granuloma lepra, sedangkan di sisi lain memberikan efek yang sangat bermakna pada granuloma tuberkulosis.Pada pasien lepra tipe tuberkuloid respon imun seluler baik yang terhadap $M$. leprae menyebabkan lesi kulit sedikit dan secara histologis terdiri dari granuloma yang kaya limfosit CD3+, CD8+, Cd4+ dengan dominasi sel T CD4. Di sisi lain, tipe lepromatosa memperlihatkan imunitas seluler yang buruk ditandai dengan pertumbuhan bakteri yang tidak terkontrol dan lesi kulit yang luas. Hal ini ditandai dengan granuloma yang terdiri dari makrofag dan sejumlah kecil sel T CD8+. Infeksi HIV akan mempengaruhi imunitas seluler dengan berkurangnya sel CD4+ sehingga menurunkan kemampuan melawan mikobakteria seperti pada infeksi M. tuberculosis², akan tetapi penelitian Sampaio dkk. memperlihatkan pasien HIV yang koinfeksi dengan lepra BT mempunyai jumlah sel T CD4+ normal dan granuloma yang terbentuk dengan baik, walaupun CD4 di sirkulasi rendah, sementara pada pasien HIV yang ko-infeksi dengan lepra tipe lepromatosa (LL) memperlihatkan histopatologi yang serupa dengan pasien HIV negatif. ${ }^{16}$ Pada koinfeksi HIV dan M. leprae, sel CD4 di darah tidak mencerminkan jumlah atau fungsi sel CD4 pada tempat terjadi ko-infeksi. ${ }^{17}$

Hal ini erat hubungannya dengan tingkat aktifitas imunologis dari sel mononuklear target. Sel yang teraktivasi lebih mudah terinfeksi HIV berhubungan dengan meningkatnya respon koreseptor kemokin dan percepatan siklus hidup virus yang ditandai dengan angka replikasi virus. Suseptibilitas relatif granuloma lepra berbeda dengan granuloma tuberkulosis dimana pada granuloma tuberkulosis, granuloma menarik sel terinfeksi HIV sehingga cenderung menyebabkan infeksi viral yang produktif dan meluas pada granuloma. Turnover sel pada granuloma tuberkulosis yang sangat tinggi cenderung berkaitan dengan tingginya tingkat penarikan sel mononuklear dari pool sel sistemik, yang meningkatkan potensi masuknya sel yang terinfeksi HIV. Lebih lanjut, viral load dan efek imunologis terhadap HIV yang maksimal pada infeksi $M$. tuberculosis menyebabkan rusaknya respons lokal granulomatosa inang. ${ }^{3,4}$ Sebaliknya, granuloma lepra mempunyai aktivasi, tingkat apoptosis, dan turnover sel yang rendah, sehingga menyebabkan risiko rendah menarik sel yang terinfeksi HIV.,2,4,15

Pengaruh terhadap respons imun lokal versus sistemik terhadap $M$. leprae secara kontras berbeda dengan respons serupa pada pasien dengan AIDS dan infeksi M. tuberculosis. Dibandingkan dengan M. leprae, M. tuberculosis mempunyai kemampuan lebih besar untuk menginduksi sekresi TNF-á, salah satu proinflamatory cytokine yang penting dalam imunopatogenesis infeksi HIV. Sebagai akibatnya, inflamasi pada tempat infeksi M. tuberculosis 
cenderung lebih kondusif untuk berkembangnya infeksi HIV dibanding infeksi M. leprae.,4

Hubungan antara infeksi lepra dan kejadian HIV yang memburuk merupakan aspek penelitian yang masih sulit dilakukan, karena tergantung pengaruh pada waktu terjadinya infeksi HIV dan infeksi tersebut tidak sekedar lepra tetapi juga infeksi oporunistik lain. Tidak ada data yang menjelaskan bahwa lepra memperburuk infeksi HIV, akan tetapi penelitian Carvalho dkk.memperlihatkan pada 28 pasien Brazil yang ko-infeksi mempunyai rasio CD4:CD8 yang rendah, tingkat aktivasi sel $\mathrm{T}$ CD8+ yang tinggi, dan menurunnya persentase plasmasitoid sel dendiritik dibanding dengan pasien dengan HIV saja. Hal-hal ini merupakan gambaran progresivitas HIV, sehingga dikatakan ko-infeksi lepra dapat memperburuk patogenesis HIV. Oleh karena hasil yang didapat tidak signifikan, penelitian lanjutan diperlukan terkait hal ini. ${ }^{1}$

Pasien ko-infeksi HIV dan M.leprae yang diterapi dengan MDT WHO memberikan respons yang cukup baik setara dengan MDT WHO pada pasien lepra dengan HIV negatif ${ }^{3}$, akan tetapi studi Sarno dkk. memperlihatkan 3-4\% angka kekambuhan pada pasien dengan ART dibanding $1 \%$ pada pasien dengan HIV negatif. Hal ini mengindikasikan bahwa pasien dengan ko-infeksi harus dimonitor lebih dekat untuk kejadian kambuh setelah pengobatan. ${ }^{15}$

\section{PENGARUH ANTI RETROVIRAL THERAPY (ART) TERHADAP KO-INFEKSI LEPRA/HIV}

Sejak pengenalan highly active antiretroviral therapy (HAART) pada manajemen HIV, terutama di daerah endemi lepra, lepra dilaporkan meningkat sebagai bagian dari sindrom pulih imun (Immune Reconstitution Inflammatory Syndrome/IRIS). ${ }^{2}$ IRIS merupakan perubahan status klinis yang paradoks setelah memulai HAART pertama kali saat angka CD4+ sangat rendah, umumnya kurang dari 200/ $\mathrm{uL}^{18}$. Hal ini terkait dengan respons imun seseorang yang kembali atau reaktivasi terhadap proses penyakit subklinis atau laten. Penyakit inflamasi muncul 1 hingga 6 bulan setelah terapi efektif dimulai, selama periode transisi replikasi virus dihambat, angka limfosit CD4+ meningkat, dan terjadi perbaikan respons imun. ${ }^{18}$ Rejimen HAART saat ini digunakan untuk meningkatkan produksi dan redistribusi sel CD4+ dan memperbaiki imunitas spesifik terhadap patogen, HIV dan patogen lain. ${ }^{3}$

Tahun 2003, 23 kasus pasien lepra dengan IRIS telah dipublikasikan, terutama pada negaranegaradengan ketersediaan ART, 70\% kasus dari Amerika Selatan dan 20\% dari India. Dari publikasi tersebut, lepra tipe borderline merupakan bentuk paling umum dan selalu ada reaksi tipe $1 .{ }^{3}$ Penelitian lain juga memperlihatkan adanya reaksi tipe 1 pada pasien-pasien lepra tipe borderline yang terinfeksi HIV setelah terapi dengan HAART. ${ }^{4}$

Untuk menentukan apakah ART dihubungkan dengan manifestasi klinis lepra yang lebih buruk, penelitian kohort oleh Sarno dkk. pada tahun 2008 dilakukan pada pasien lepra antara tahun 1996 2006 di klinik rawat jalan lepra Oswaldo Cruz Foundation (FIOCRUZ) di Rio de Janeiro Brazil. Hasil penelitian ini memperlihatkan pasien HIV terdiagnosa lepra setelah mendapatkan ART dengan tipe terbanyak adalah lepra tipe tuberkuloid/ pausibasiler dengan jumlah bakteri yang rendah. Pada individu yang terinfeksi HIV, diagnosis lepra dihubungkan dengan status imun yang membaik ditandai dengan angka limfosit CD4+ lebih tinggi dan viral load yang rendah. Peningkatan angka CD4 setelah HAART dimulai akan mengakibatkan perbaikan sistem imun innate yang dimediasi natural killer cells (sel NK) dan makrofag sebagai tambahan penguatan respons imun diperantarai sel T yang spesifik lepra. ${ }^{15}$

HAART akan memicu manifestasi klinis koinfeksi dengan tuberkulosis, limfadenitis, sitomegalovirus, herpes zoster, hepatitis B dan C virus, dan lepra. ${ }^{18}$ Kasus lepra dapat dihubungkan dengan IRIS apabila memenuhi persyaratan sebagai berikut $^{2}$ : 1) lepra atau reaksi lepra terjadi dalam 6 bulan HAART dimulai; 2) infeksi HIV lanjut; 3) CD4+ rendah dihitung sebelum memulai HAART; 4) CD4+ meningkat setelah pemberian HAART .

Penjelasan yang mungkin untuk lepra yang berhubungan dengan IRIS ${ }^{3}$, yaitu lepra mempunyai periode inkubasi yang panjang, dan bentuk lepra tuberkuloid dan borderline membutuhkan imun seluler yang spesifik untuk $M$. lepra agar dapat terjadi lesi kulit, sehingga HAART menjadi pemicu respon imunologis yang menyebabkan terjadinya presentasi lepra. Hipotesis lain adalah ko-infeksi HIV menyebabkan supresi respons imun inang 
terhadap M. Leprae yang kemudian respons inang kembali setelah memulai HAART. $^{3}$

\section{DAFTAR PUSTAKA}

1. Carvalho KI, Maeda S, Marti L, et al. Immune cellular parameters of leprosy and human immunodeficiency virus-1 co-infected subjects. Immunology. 2008;124(2):206-14.

2. Lockwood DNJ, Lambert SM. Leprosy and HIV, where are we at? Leprosy review. 2010;81(3):169-75.

3. Ustianowski AP, Lawn SD, Lockwood DNJ. Interactions between HIV infection and leprosy: a paradox. The Lancet infectious diseases. 2006;6(6):350-60.

4. Pereira G a S, Stefani MM a, Araújo Filho J a, et al. Human immunodeficiency virus type 1 (HIV-1) and Mycobacterium leprae coinfection: HIV-1 subtypes and clinical, immunologic, and histopathologic profiles in a Brazilian cohort. The American journal of tropical medicine and hygiene. 2004;71(5):67984.

5. Eichelmann K, González González SE, SalasAlanis JC, Ocampo-Candiani J. Leprosy. An update: definition, pathogenesis, classification, diagnosis, and treatment. Actas dermosifiliográficas. 2013;104(7):554-63.

6. Chatterjee D, Khoo KH. Mycobacterial lipoarabinomannan: an extraordinary lipoheteroglycan with profound physiological effects. Glycobiol. 1998;8(2):113-20.

7. Abulafia J, Vignale R a. Leprosy: pathogenesis updated. International journal of dermatology. 1999;38(5):321-34.

8. Cowley S. The biology of HIV infection. Leprosy Review. 2001:212-220.

9. Prentice $\mathrm{H}$ a., Tang J. HIV-1 Dynamics: A Reappraisal of Host and Viral Factors, as well as Methodological Issues. Viruses. 2012;4(10):2080-2096.
10. Macleod IJ. Molecular virology of human immunodeficiency virus (HIV). 2010. Available at: $\mathrm{h}>\mathrm{p}: / / w w w . h s p h . h a r v a r d . e d u / r e s e a r c h / i a i n-$ - macleod/teaching/.

11. Fanales-Belasio E. HIV virology and pathogenetic mechanisms of infection: a brief overview. Ann Ist Super Sanita A. 2010:5-14.

12. Kresno SB. Imunologi: Diagnosis dan Prosedur Laboratorium. 5th ed. Jakarta: Badan Penerbit Fakultas Kedokteran Universitas Indonesia; 2010.

13. Fauci A. Pathogenesis of HIV disease: opportunities for new prevention interventions. Clinical infectious diseases. 2007;20892(Suppl 4).

14. Talhari C, Mira MT, Massone C, et al. Leprosy and HIV coinfection: a clinical, pathological, immunological, and therapeutic study of a cohort from a Brazilian referral center for infectious diseases. The Journal of infectious diseases. 2010;202(3):345-54.

15. Sarno EN, Illarramendi X, Nery JC, et al. HIVM. leprae interaction: can HAART modify the course of leprosy? Public health reports (Washington, D.C./ : 1974). 2008;123(2):20612.

16. Sampaio EP, Caneshi JR, Nery JA, Duppre NC. Cellular immune response to Mycobacterium leprae infection in human immunodeficiency virus-infected individuals. Infection and Immunology. 1995;63(5):1548-54.

17. Sampaio LH, Stefani MM, Oliveira RM, et al. Immunologically reactive $M$. leprae antigens with relevance to diagnosis and vaccine development. BMC infectious diseases. 2011;11:26.

18. Couppié $\mathrm{P}$, Abel S, Voinchet $\mathrm{H}$, et al. Immune reconstitution inflammatory syndrome associated with HIV and leprosy. Archives of dermatology. 2004;140(8):997-1000. 